Article

\title{
Evaluating Performance of Public Transport Networks by Using Public Transport Criteria Matrix Analytic Hierarchy Process Models-Case Study of Stonnington, Bayswater, and Cockburn Public Transport Network
}

\author{
Gang Lin ${ }^{1}$, Shaoli Wang ${ }^{2, *}$, Conghua Lin ${ }^{2}$, Linshan $\mathrm{Bu}^{1}$ and Honglei $\mathrm{Xu}^{1}$ \\ 1 School of Electrical Engineering, Computing and Mathematical Sciences, Curtin University, \\ Perth, WA 6845, Australia; Gang.lin@postgrad.curtin.edu.au (G.L.); \\ linshan.bu@postgrad.curtin.edu.au (L.B.); h.xu@curtin.edu.au (H.X.) \\ 2 School of Architecture and Planning, Fujian University of Technology, Fuzhou 350118, China; \\ lchlxrlg@126.com \\ * Correspondence: shaoli.w@gmail.com
}

\section{check for}

updates

Citation: Lin, G.; Wang, S.; Lin, C.; $\mathrm{Bu}, \mathrm{L} . ; \mathrm{Xu}, \mathrm{H}$. Evaluating Performance of Public Transport Networks by Using Public Transport Criteria Matrix Analytic Hierarchy Process Models-Case Study of Stonnington, Bayswater, and Cockburn Public Transport Network. Sustainability 2021, 13, 6949. https:// doi.org/10.3390/su13126949

Academic Editor: Aoife Ahern

Received: 5 May 2021

Accepted: 16 June 2021

Published: 21 June 2021

Publisher's Note: MDPI stays neutral with regard to jurisdictional claims in published maps and institutional affiliations.

Copyright: (c) 2021 by the authors. Licensee MDPI, Basel, Switzerland. This article is an open access article distributed under the terms and conditions of the Creative Commons Attribution (CC BY) license (https:/ / creativecommons.org/licenses/by/ $4.0 /)$.
Abstract: To mitigate car traffic problems, the United Nations Human Settlements Programme (UNHabitat) issued a document that provides guidelines for sustainable development and the promotion of public transport. The efficiency of the policies and strategies needs to be evaluated to improve the performance of public transportation networks. To assess the performance of a public transport network, it is first necessary to select evaluation criteria. Based on existing indicators, this research proposes a public transport criteria matrix that includes the basic public transport infrastructure level, public transport service level, economic benefit level, and sustainable development level. A public transport criteria matrix AHP model is established to assess the performance of public transport networks. The established model selects appropriate evaluation criteria based on existing performance standards. It is applied to study the Stonnington, Bayswater, and Cockburn public transport network, representing a series of land use and transport policy backgrounds. The local public transport authorities can apply the established transport criteria matrix AHP model to monitor the performance of a public transport network and provide guidance for its improvement.

Keywords: PT network performance criteria; criteria selection; case study

\section{Introduction}

Worldwide, metropolitan areas of numerous countries are facing a set of urgent issues related to the growing trend of private car usage and the subsequent damage to the environment [1]. In response to these issues, one major approach is to use public transport [2]. In 2015, the United Nations Human Settlements Programme (UN-Habitat) issued a document giving guidance on urban and territorial sustainable development, especially regarding the promotion of public transport [3]. However, the effectiveness of these policies and strategies is difficult to define. Therefore, the accurate performance assessment of public transport is important.

There are three major methods for measuring the efficiency of public transport networks: stochastic frontier analysis (SFA), analytic hierarchy process (AHP), and data envelopment analysis (DEA) [4-6]. Both SFA and DEA focus only on measuring production efficiency related to economic theory [5]. The application areas of AHP include performance type issues, public policy, strategy, and planning [7]. AHP enables decision makers to deal with complex problems involving subjective criteria and multiple conflicts [8,9]. As for public transport, stakeholders are interested in direct and external effects [9], and AHP covers the economic benefit, quality and efficiency of the public transport service, the basic public transport infrastructure, and the sustainable development level [9]. Based on these, 
the AHP model can help governments monitor and improve the performance of public transportation networks in a more efficient way. Thus, this paper aims to use the AHP model to develop a criteria matrix AHP model to evaluate public transport networks and help decision makers assess and improve the performance of public transport networks.

The contributions of this research are threefold: first, the main contribution is the creation of a comprehensive evaluation model that considers both the direct and external effects of the use of public transportation; second, the model evaluates the performance of the public transport network, which is combined with the detail standards-the sub-criteria can then be evaluated according to the level scale; third, the government can improve performance based on the results of the model-improvement goals can be based on each level grade standard for the sub-criteria.

The paper is organized as follows: Section 2 presents a review of the previous studies on evaluation criteria related to public transport network performance. It also introduces the AHP model and establishes the public transport criteria matrix AHP model. The motivation and characteristics of the three case study areas are described in Section 3. Section 4 identifies the results of applying the established model to evaluate the public transport network performance of the three case study areas, and Section 5 demonstrates the contributions of the proposed model and offers suggestions for future research.

\section{Materials and Methods}

\subsection{Evaluation Criteria}

To evaluate the performance of a public transport network, researchers generally apply the six measurement systems listed in Table 1.

Table 1 shows that much of the research on public transport evaluation focuses on operations and services. It does not fully study the comprehensive impact of other key factors, such as development policies, energy/sustainability, and infrastructure/facilities, on the development of urban transportation systems. The research lacks a multi-standard framework for public transport network evaluation at multiple application levels, which requires the consideration of multiple subjective and conflicting criteria.

\subsection{AHP Model}

The AHP is a method of multiple-criteria decision-making (MCDM); it enables the decision maker to address complicated issues that involve multiple subjective and conflicting criteria [6]. The issue is deconstructed into various levels in the AHP [19]. The AHP offers an ordered framework of options from the most preferential to the least preferential [19]. Moreover, it is the most commonly used MCDM tool for solving problems that have multiple objectives [20]. It prioritizes alternatives into qualitative and quantitative terms based on a set of objectives [21]. The factors at each level are produced through pairwise comparisons, which requires the relative importance to be assigned between two criteria or two sub-criteria [19]. Moreover, the AHP also can be used to rank performance [22]. The three main processes of the AHP are shown as follows:

- Priority: The element priority weight at each level is calculated using least square analysis or eigenvectors. Until the decision is achieved by using the global weight, this procedure will be repeated for each hierarchy level [23];

- Issue decomposition: The issue is broken down into elements (the elements are grouped at different levels to form a hierarchy chain), and each factor is broken down further into sub-factors until the lowest hierarchy level [22];

- Comparison analysis: Each factor's relative importance at a particular level is measured by a pairwise comparison process [22]. The decision makers and policy makers use a rating scale to produce a numerical value for each factor's priority [22].

The process of the AHP model calculation is shown in Figure 1. 
Table 1. List of measurement systems to evaluate public transport [10-18].

\begin{tabular}{|c|c|c|c|}
\hline Measurement System & Evaluation Criteria & Method & Reference \\
\hline $\begin{array}{c}\text { Public transport } \\
\text { level-of-service (LOS) }\end{array}$ & $\begin{array}{l}\text { Travel speed, acceleration and } \\
\text { braking, temporal spacing } \\
\text { between vehicles, buffer times, } \\
\text { space within vehicle, share of } \\
\text { dedicated rights-of-way, type } \\
\text { of road, type of transit stop, } \\
\text { density within vehicle, } \\
\text { on-time performance, } \\
\text { headway adherence, service } \\
\text { duration }\end{array}$ & $\begin{array}{l}\text { Determines the score for } \\
\text { public transport LOS for } \\
\text { public transport elements. The } \\
\text { score helps the decision } \\
\text { makers to evaluate the public } \\
\text { transport service. }\end{array}$ & $\begin{array}{c}\text { (Orth et al., 2012), } \\
\text { (Tiznado-Aitken et al., 2021) }\end{array}$ \\
\hline $\begin{array}{l}\text { Buses with high level of } \\
\text { service (BHLS) }\end{array}$ & $\begin{array}{c}\text { Vehicle running time and rest } \\
\text { time, reliability, demand } \\
\text { patterns, total vehicle trip } \\
\text { time, layover and recovery } \\
\text { times, passenger waiting time, } \\
\text { passenger in-vehicle time, } \\
\text { passenger travel time, } \\
\text { monetary values, operator } \\
\text { costs }\end{array}$ & $\begin{array}{l}\text { Analyzes the influence of a } \\
\text { series of public transport } \\
\text { operational measures and } \\
\text { design by assessing the } \\
\text { impact of reliability on } \\
\text { expenses associated with } \\
\text { saving passenger travel time } \\
\text { and fleet operations }\end{array}$ & (Fadaei and Cats 2016) \\
\hline $\begin{array}{l}\text { Public transport } \\
\text { quality indicators }\end{array}$ & $\begin{array}{l}\text { Offer of services, accessibility, } \\
\text { information, time, attention } \\
\text { given to passengers, comfort, } \\
\text { safety and security, effects on } \\
\text { the environment }\end{array}$ & $\begin{array}{l}\text { Evaluates the public } \\
\text { transportation service quality } \\
\text { and sustainable level }\end{array}$ & $\begin{array}{c}\text { (Dragu et al., 2013) } \\
\text { (Barabino et al., 2020) }\end{array}$ \\
\hline $\begin{array}{l}\text { Performance importance } \\
\text { matrix }\end{array}$ & $\begin{array}{c}\text { Bus punctuality, bus } \\
\text { condition, new fleet addition, } \\
\text { seating for elderly, ticket } \\
\text { system, service system, bus } \\
\text { facility, stopping bus at correct } \\
\text { place, driver behavior, } \\
\text { information to passengers }\end{array}$ & $\begin{array}{l}\text { Identifies the strong and weak } \\
\text { areas and general public } \\
\text { transport performance }\end{array}$ & (Sezhian et al. 2011) \\
\hline SNAMUTS & $\begin{array}{c}\text { Minimum service standard, } \\
\text { activity nodes, travel } \\
\text { impediment, weekday } \\
\text { inter-peak }\end{array}$ & $\begin{array}{l}\text { Assesses the connectivity and } \\
\text { centrality of urban public } \\
\text { transportation networks in } \\
\text { terms of land use and include } \\
\text { its market level in the choice } \\
\text { of multimodal transport. }\end{array}$ & $\begin{array}{l}\text { (Curtis and Scheurer 2017) } \\
\text { (Curtis and Scheurer 2019) }\end{array}$ \\
\hline Transit service quality & $\begin{array}{l}\text { Availability, accessibility, } \\
\text { customer care, time, safety } \\
\text { and security, comfort and } \\
\text { amenities }\end{array}$ & $\begin{array}{c}\text { Evaluates the transit system } \\
\text { service quality }\end{array}$ & (De Ona et al., 2016) \\
\hline
\end{tabular}

(1) Comparison of the importance between each pair:

The value $\left(c_{i g}\right)$ is assigned to represent the importance (from 1 to 9 ) for attribute $(i)$ and attribute $(g)$; additionally, $c_{i g}=1 / c_{g i}$. Next, a decision matrix is created, which is matrix $C=\left(c_{i g}\right)$.

(2) Normalization of pairwise comparison matrix:

The pairwise comparison matrix needs to be normalized using the normalized arithmetic averages method [24]. After the normalization, matrix $C$ is transformed into matrix $D=\left(d_{i g}\right)$. The formula of matrix $D$ is shown as follows:

$$
d_{i g}=\frac{c_{i g}}{\sum_{i=1}^{n} C_{i g}}
$$




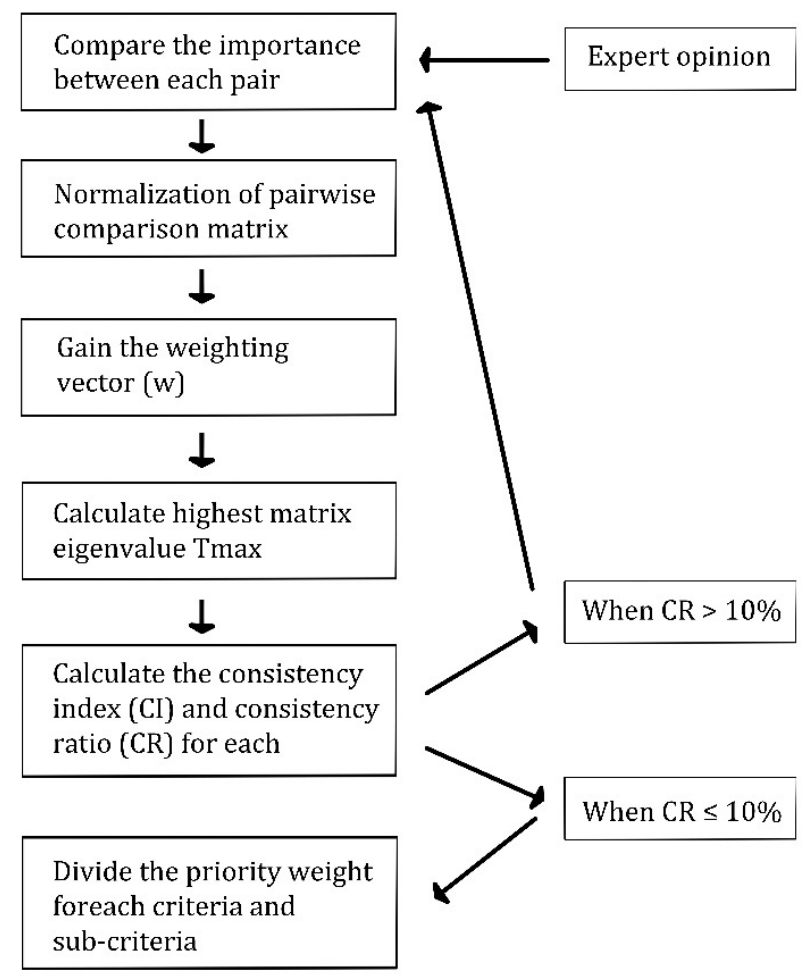

Figure 1. AHP model calculation process [21,22].

(3) Obtaining the weighting vector $(w)$ :

The prioritization vector $(w)$ is gained by calculating the arithmetic averages from the normalized comparison matrix $\left(d_{i g}\right)$ row. The calculation of vector $\mathrm{w}$ is calculated as below:

$$
w=\frac{\sum_{g=1}^{n} d_{i g}}{n}
$$

(4) Calculation of the highest matrix eigenvalue $T_{\max }$ :

Next, the highest matrix eigenvalue is calculated. The highest eigenvalue $T_{\max }$ is satisfied by:

$$
\mathrm{Cw}=T_{\max } \text { and } T_{\max } \approx T=\frac{\sum_{i=1}^{n} T_{i}}{n}
$$

(5) Calculation of the consistency index $(C I)$ and consistency ratio $(C R)$ for each comparison matrix $C$ :

The researcher tests that the ratings given by the experts are consistent. $T_{\max }$ is the highest eigenvalue of the matrix, $n$ is the number of objects which are compared, RI (Table 2) is the random index, and $n$ is the matrix dimension. The RI is shown as below:

Table 2. Random Index (RI) [25].

\begin{tabular}{cccccccccc}
\hline Matrix Size & $\mathbf{1}$ & $\mathbf{2}$ & $\mathbf{3}$ & $\mathbf{4}$ & $\mathbf{5}$ & $\mathbf{6}$ & $\mathbf{7}$ & $\mathbf{8}$ & $\mathbf{9}$ \\
\hline Random consistency index & 0.00 & 0.00 & 0.58 & 0.90 & 1.12 & 1.24 & 1.32 & 1.41 & 1.45 \\
\hline
\end{tabular}

Furthermore, the calculation details of $C I$ and $C R$ for each comparison matrix $C$ are calculated as follows:

$$
\begin{gathered}
C I=\frac{T_{\max }-n}{n-1} \\
C R=\frac{C I}{R I}
\end{gathered}
$$


When $C R \leq 10 \%$, the comparisons are considered as internally coherent; otherwise, it would be considered that inconsistency was present during the comparison process.

This study uses the AHP model to develop a comprehensive multi-criteria public transport network performance evaluation model for various application levels.

The criteria and standards of the model are demonstrated in the following section.

\subsection{Public Transport Criteria Matrix AHP Model}

This study selects the criteria and standards of the proposed model based on four levels, which are the economic benefit level, the quality and efficiency of the public transport service level, the basic public transport infrastructure level, and the sustainable development level. Based on the above considerations, the criteria are selected from the Evaluation Index System of Public Transportation City Assessment [26], the Code for Transport Planning on Urban Road GB50220-1995 [27], the Passenger Transport Services for Bus/Trolleybus GB/T22484-2008 [28], GBT 22484-2016, the Passenger Transport Services Specifications for Urban Bus/Trolleybus [29], and the Urban Road Traffic Management Evaluation Index System (2012 edition) [30].

Following these criteria, the model divides the criteria into two levels, which are (1) the urban level, and (2) the company operation level. In particular, the model makes the following definitions:

(1) Urban level: Public transport is considered at the urban level to evaluate the urban public transport management and infrastructure establishment. The detailed expression of each criterion is described as follows:

- The public transport network ratio refers to the proportion of the length of the public transportation network to the length of the urban road network, which reflects the service capacity and scope of urban public transportation;

- The public transport coverage ratio reflects the convenience of using the public transportation system for residents. It refers to the ratio of the urban public transportation service area to the urban land area;

- The arbor-type bus stop setting ratio indicates the capacity of buses and the government's guarantees of bus priority. It considers the number of stations with bus stop bays on the expressways, main roads, and secondary roads in the city and accounts for the proportion of the total number of stops on the expressways, main roads, and secondary roads in the city;

- The public transportation priority lane setting ratio shows the proportion of the road length of public transport priority lanes in relation to the total length of the urban main roads in the city. The length of the roads with public transport priority lanes refers to the length of the center line of the roads with public transport priority lanes in the city. This is an important indicator that needs to be monitored to improve the traffic conditions of urban public transportation vehicles, and it reflects the level of a city's emphasis on public transportation priority policies;

- The public transport land area per capita refers to the ratio of the area of public transport roads to the total urban population. This represents land use for public transportation;

- The public transport utilization rate refers to the degree of coincidence between land used for public transportation and planned land use in the same period. This criterion is expressed as the ratio of the number of jobs in public transportation to the total number of jobs during the same period. It reflects the consistency of public transport with the city's master plan;

- The green public transport vehicle rate is the proportion of green public transport vehicles to total public transport vehicles during the statistical period. Green public transportation vehicles include subways, light rail vehicles, trams, new energy vehicles, trolleybuses, liquid petroleum gas (LPG) vehicles, etc. It reflects the important indicators of energy conservation and environmental protection of urban public transportation systems; 
- The public transport energy intensity is the ratio of the total energy consumption of urban public transport to the volume of passenger transport of urban public transport. It reflects the energy consumed to complete a unit of passenger turnover. This indicator reflects the energy conservation and environmental protection of an urban public transportation system. This indicator has a high correlation with the number and type of energy of vehicles employed.

(2) Company operation level: This level considers public transport from the company level to evaluate the public transport operators. The details are shown as follows:

- The public transport on-time rate indicates the average of buses' on-time rates and rail transit's on-time rate. The departure time of a bus is the first departure time of the bus. If the actual departure time is less than 2 min later than the planned departure time, it will be recorded that the departure time is punctual. The arrival time at the last station means that the actual arrival time at the last station is within the range of being 2 min earlier than the planned schedule or less than 5 min late, which is recorded as the arrival time at the last station. This is recorded as a delay when a rail transit train leaves or arrives at the terminal at the departure station greater than or equal to $2 \mathrm{~min}$ later compared to the planned time of the train schedule;

- The intersection blocking rate during peak hours is an indicator that measures the saturation of the entire road network. A periodically blocked intersection is frequently blocked for a certain period, such as in the AM and PM peaks (and the blocked intersections are not caused by accidents). This is also a basis for checking the effects of traffic management, the development of traffic demand management measures, and proposing intersection reconstruction planning;

- The passenger freight rate is the ratio of the cost of public transportation paid by an ordinary passenger per month to the average city salary for that month. This index can reflect the rationality and affordability of ticket prices;

- The public transport driving accident rate is the number of accidents per million $\mathrm{kms}$ travelled by public transport vehicles in a year. This is an important criterion to reflect the safety performance of the public transportation system and has a high correlation with the use and maintenance of public transportation vehicles;

- The coverage rate refers to the rate of total commercial revenue of the last year to the total operating expenses of the last year. It shows the user financial contribution and the economic sustainability of the operators;

- The bus ownership rate refers to the number of bus stations per 10,000 people in the statistical period. It reflects the distribution of traffic structure;

- The intact car rate is the ratio of intact vehicle days to operating vehicle days during the statistical period. It shows the maintenance level of public transportation.

An overview of the formula for the sub-criteria and level grade for all sub-criteria can be found in Tables A1 and A2. It can be seen from Table A2 that level A shows the best performance regarding the criteria, and level $\mathrm{E}$ means ordinary performance. The process for measuring the city score is indicated as follows:

- First, data for each criterion need to be collected from the relevant planning and public transportation departments;

- Second, the calculated data are ranked according to established performance standards;

- Third, the global weight for each sub-criterion is calculated as the weight of the criteria (main criteria prioritization) multiplied by the sub-criteria weight (sub-criteria prioritization);

- Finally, based on the established public transport network performance score levels, the public transport performance grade for a city can be measured.

\section{Case Study}

The evaluation model described in the previous section was applied to the three Australian case study areas-(1) the City of Stonnington, (2) the City of Bayswater, and (3) 
the City of Cockburn - to examine the public transport criteria matrix AHP model. Stonnington's location is close to Melbourne's Central Business District (CBD), and Bayswater's location is adjacent to Perth's CBD. Cockburn is in the southern part of the Perth CBD. The population densities of Bayswater, Cockburn, and Stonnington are 19.94 persons per hectare, 6.98 persons per hectare, and 46.27 persons per hectare, respectively. The main designation of these three cities is residential. The length of Bayswater's public transport network is approximately $61.9117 \mathrm{~km}$, Cockburn's is $147.9874 \mathrm{~km}$, and Stonnington's is approximately $74.7598 \mathrm{~km}$. The details of three case studies are concluded in Table 3 .

Table 3. Details of three case studies.

\begin{tabular}{cccc}
\hline City & Bayswater & Cockburn & Stonnington \\
\hline Population density & $\begin{array}{c}\text { 19.94 persons } \\
\text { per hectare }\end{array}$ & $\begin{array}{c}6.98 \text { persons } \\
\text { per hectare }\end{array}$ & $\begin{array}{c}46.27 \text { persons } \\
\text { per hectare }\end{array}$ \\
\hline $\begin{array}{c}\text { Length of public } \\
\text { transport network }\end{array}$ & $61.9117 \mathrm{~km}$ & $147.9874 \mathrm{~km}$ & $74.7598 \mathrm{~km}$ \\
\hline $\begin{array}{c}\text { Predominant purpose } \\
\text { of case study area }\end{array}$ & Residential & Residential & Residential \\
\hline $\begin{array}{c}\text { Main type of } \\
\text { public transport }\end{array}$ & Bus and train & Bus and train & Bus and train \\
\hline
\end{tabular}

All of the case study areas have a well-established public transport network. The main types of public transport in the three cities are buses and trains. As the population of the three case study cities continues to grow, the government requires an assessment of the existing public transport networks. All three governments have created new strategies and plans to promote public transportation, but car ownership in Melbourne and Perth continues to increase. This is the motivation for a comparison study of the three cities. The city boundaries of the three case study areas are shown in Figure 2.

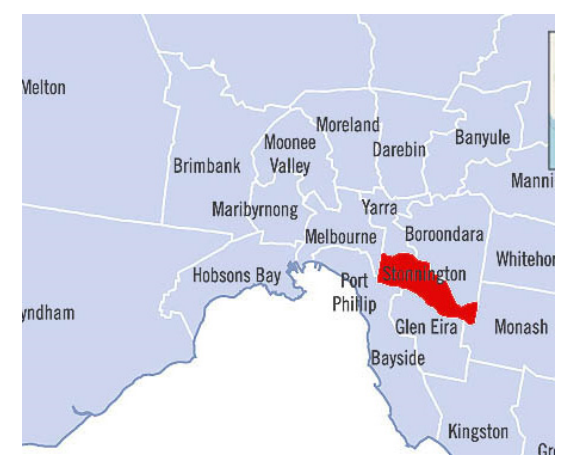

(a)

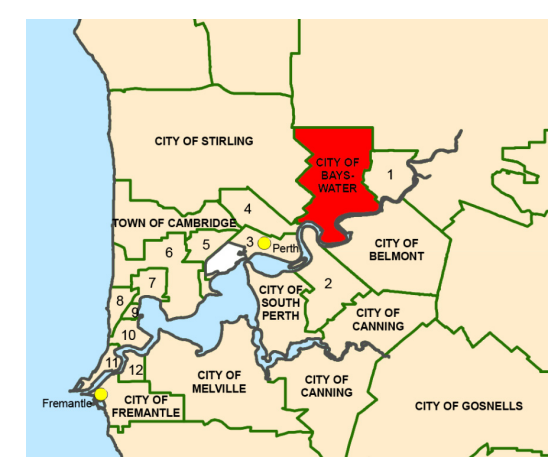

(b)

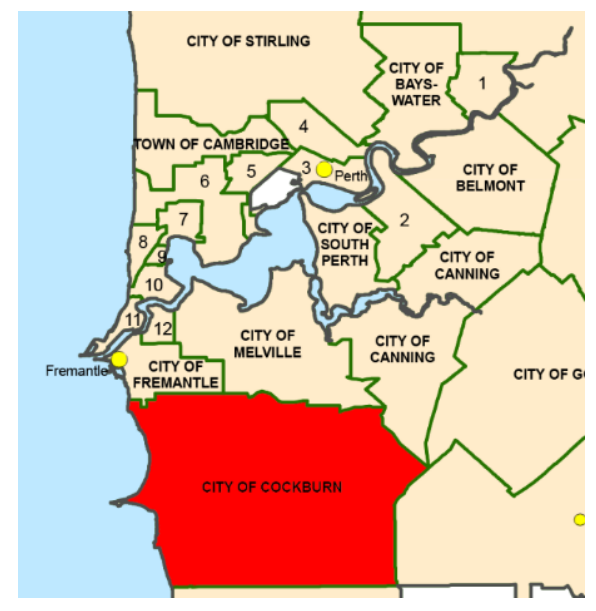

(c)

Figure 2. (a) City boundary of Stonnington; (b) city boundary of Bayswater; (c) city boundary of Cockburn.

\section{Findings}

In this section, the proposed model is applied to the public transport network performance of the case study areas in terms of the basic public transport infrastructure level, public transport service level, economic benefit level, and sustainable development level.

The pairwise comparison matrix was defined by studying the polices of the local councils in the case study areas. Table 4 presents the preference matrix of the four main 
criteria, taking the overall weight for the basic public transport infrastructure level as $41 \%$, for the public transport service level as 19\%, for the economic benefit level as $11 \%$, and for the sustainable development level as $29 \%$. The local weights for the sub-criteria (sub-criteria prioritization) are shown in Tables 5-8. Based on the weights for the criteria and sub-criteria, the global weight for each sub-criterion is shown in Table 9.

Table 4. Preference matrix, prioritization, CI, and CR for the four main criteria.

\begin{tabular}{|c|c|c|c|c|c|c|c|}
\hline & $\begin{array}{l}\text { Basic Public } \\
\text { Transport In- } \\
\text { frastructure } \\
\text { Level }\end{array}$ & $\begin{array}{l}\text { Public } \\
\text { Transport } \\
\text { Service } \\
\text { Level }\end{array}$ & $\begin{array}{c}\text { Economic } \\
\text { Benefit Level }\end{array}$ & $\begin{array}{c}\text { Sustainable } \\
\text { Develop- } \\
\text { ment } \\
\text { Level }\end{array}$ & Prioritization & CI & CR \\
\hline $\begin{array}{l}\text { Basic public transport } \\
\text { infrastructure level }\end{array}$ & 1 & 2 & 3 & 2 & $41 \%$ & $2.72 \%$ & $3.02 \%$ \\
\hline $\begin{array}{l}\text { Public transport } \\
\text { service level }\end{array}$ & $1 / 2$ & 1 & 2 & $1 / 2$ & $19 \%$ & & \\
\hline Economic benefit level & $1 / 3$ & $1 / 2$ & 1 & $1 / 3$ & $11 \%$ & & \\
\hline $\begin{array}{c}\text { Sustainable } \\
\text { development level }\end{array}$ & $1 / 2$ & 2 & 3 & 1 & $29 \%$ & & \\
\hline
\end{tabular}

Table 5. Preference matrix, prioritization, CI, and CR for basic public transport infrastructure level.

\begin{tabular}{|c|c|c|c|c|c|c|c|}
\hline & $\begin{array}{c}\text { Public } \\
\text { Transport } \\
\text { Network } \\
\text { Ratio }\end{array}$ & $\begin{array}{c}\text { Public } \\
\text { Transport } \\
\text { Coverage } \\
\text { Ratio }\end{array}$ & $\begin{array}{l}\text { Harbor Type } \\
\text { Bus Stop } \\
\text { Setting Ratio }\end{array}$ & $\begin{array}{c}\text { Public Trans- } \\
\text { portation } \\
\text { Priority Lane } \\
\text { Setting Ratio }\end{array}$ & Prioritization & CI & CR \\
\hline $\begin{array}{l}\text { Public transport } \\
\text { network ratio }\end{array}$ & 1 & 1 & 3 & 2 & $35 \%$ & $0.27 \%$ & $0.3 \%$ \\
\hline $\begin{array}{l}\text { Public transport } \\
\text { coverage ratio }\end{array}$ & 1 & 1 & 3 & 2 & $35 \%$ & & \\
\hline $\begin{array}{l}\text { Harbor type bus stop } \\
\text { setting ratio }\end{array}$ & $1 / 2$ & $1 / 2$ & 1 & $1 / 2$ & $11 \%$ & & \\
\hline $\begin{array}{l}\text { Public transportation } \\
\text { priority lane setting ratio }\end{array}$ & $1 / 3$ & $1 / 3$ & 2 & 1 & $19 \%$ & & \\
\hline
\end{tabular}

Table 6. Preference matrix, prioritization, CI, and CR for public transport service level.

\begin{tabular}{|c|c|c|c|c|c|c|c|}
\hline & $\begin{array}{l}\text { Public } \\
\text { Transport } \\
\text { On-Time } \\
\text { Rate }\end{array}$ & $\begin{array}{l}\text { Intersection } \\
\text { Blocking } \\
\text { Rate during } \\
\text { Peak Hours }\end{array}$ & $\begin{array}{l}\text { Passenger } \\
\text { Freight Rate }\end{array}$ & $\begin{array}{c}\text { Public } \\
\text { Transport } \\
\text { Driving } \\
\text { Accident } \\
\text { Rate }\end{array}$ & Prioritization & CI & CR \\
\hline $\begin{array}{l}\text { Public transport } \\
\text { on-time rate }\end{array}$ & 1 & 2 & 1 & 2 & $34 \%$ & $2.18 \%$ & $2.42 \%$ \\
\hline $\begin{array}{l}\text { Intersection blocking } \\
\text { rate during peak hours }\end{array}$ & $1 / 2$ & 1 & 1 & 2 & $24 \%$ & & \\
\hline Passenger freight rate & 1 & 1 & 1 & 2 & $28 \%$ & & \\
\hline $\begin{array}{l}\text { Public transport driving } \\
\text { accident rate }\end{array}$ & $1 / 2$ & $1 / 2$ & $1 / 2$ & 1 & $14 \%$ & & \\
\hline
\end{tabular}


Table 7. Preference matrix, prioritization, $\mathrm{CI}$, and CR for economic benefit level.

\begin{tabular}{ccccccc}
\hline & Coverage Rate & Bus Ownership Rate & Intact Car Rate & Prioritization & CI & CR \\
\hline Coverage rate & 1 & 1 & 3 & $44 \%$ & $0.91 \%$ & $1.57 \%$ \\
\hline Bus ownership rate & 1 & 1 & 2 & $39 \%$ & \\
\hline Intact car rate & $1 / 3$ & $1 / 2$ & 1 & $17 \%$ & \\
\hline
\end{tabular}

Table 8. Preference matrix, prioritization, $\mathrm{CI}$, and CR for sustainable development level.

\begin{tabular}{|c|c|c|c|c|c|c|c|}
\hline & $\begin{array}{c}\text { Public } \\
\text { Transport } \\
\text { Land Area } \\
\text { per Capita }\end{array}$ & $\begin{array}{c}\text { Public } \\
\text { Transport } \\
\text { Utilization } \\
\text { Rate }\end{array}$ & $\begin{array}{c}\text { Green } \\
\text { Public } \\
\text { Transport } \\
\text { Vehicle Rate }\end{array}$ & $\begin{array}{c}\text { Public } \\
\text { Transport } \\
\text { Energy } \\
\text { Intensity }\end{array}$ & Prioritization & CI & CR \\
\hline $\begin{array}{l}\text { Public transport land } \\
\text { area per capita }\end{array}$ & 1 & 2 & 1 & 1 & $27 \%$ & $0.6 \%$ & $0.67 \%$ \\
\hline $\begin{array}{l}\text { Public transport } \\
\text { utilization rate }\end{array}$ & $1 / 2$ & 1 & $1 / 3$ & $1 / 3$ & $11 \%$ & & \\
\hline $\begin{array}{l}\text { Green public transport } \\
\text { vehicle rate }\end{array}$ & 1 & 3 & 1 & 1 & $31 \%$ & & \\
\hline $\begin{array}{l}\text { Public transport } \\
\text { energy intensity }\end{array}$ & 1 & 3 & 1 & 1 & $31 \%$ & & \\
\hline
\end{tabular}

Table 10 illustrates the original data and achieved grade of the public transportation network performance for Bayswater, Cockburn, and Stonnington. The results show that Stonnington has the highest level in terms of the public transport network ratio, public transport coverage ratio, public transportation priority lane setting ratio, intersection blocking rate during peak hours, and coverage rate. All of the cities achieve level A for the passenger freight rate, intact car rate, public transport utilization rate, and green public transport vehicle rate. Compared to Stonnington, both Bayswater and Cockburn achieve higher levels for the public transport on-time rate, public transport driving accident rate, public transport land area per capita, and public transport energy intensity. Moreover, all three case study areas only achieve level D for the bus ownership rate. Bayswater has the lowest level of public transport coverage ratio and intersection blocking rate during peak hours.

According to the standard scoring interval, we divided each city's public transportation network performance into five levels (Table 11). We calculated the scores for public transportation performance for all of the criteria and summed the performance over all criteria, as indicated in Table 12. The results show that Stonnington's public transportation network, at 82.45, scores higher than Cockburn and Bayswater, while Cockburn's public transport network scores 66.61, which is higher than Bayswater's score of 63.55. The analysis shows us that the area with the best practice in terms of public transportation is Stonnington.

According to the classification standard, the outcome of the city score (Table 12) shows that Stonnington is classified as level B, while Cockburn's and Bayswater's public transport networks' performances are both rated as level D. 
Table 9. City score distribution matrix.

\begin{tabular}{|c|c|c|}
\hline Criteria & Local Weight (\%) & Global Weight (\%) \\
\hline \multicolumn{3}{|l|}{ Basic public transport infrastructure level: $41 \%$} \\
\hline Public transport network ratio & 35 & 14.3 \\
\hline Public transport coverage ratio & 35 & 14.3 \\
\hline Harbor type bus stop setting ratio & 11 & 4.5 \\
\hline Public transportation priority lane setting ratio & 19 & 7.9 \\
\hline \multicolumn{3}{|l|}{ Public transport service level: $19 \%$} \\
\hline Public transport on-time rate & 34 & 6.5 \\
\hline Intersection blocking rate during peak hours & 24 & 4.6 \\
\hline Passenger freight rate & 28 & 5.3 \\
\hline Public transport driving accident rate & 14 & 2.6 \\
\hline \multicolumn{3}{|l|}{ Economic benefit level: 11\% } \\
\hline Coverage rate & 44 & 4.8 \\
\hline Bus ownership rate & 39 & 4.3 \\
\hline Intact car rate & 17 & 1.9 \\
\hline \multicolumn{3}{|l|}{ Sustainable development level: $29 \%$} \\
\hline Public transport land area per capita & 27 & 7.8 \\
\hline Public transport utilization rate & 11 & 3.2 \\
\hline Green public transport vehicle rate & 31 & 9 \\
\hline Public transport energy intensity & 31 & 9 \\
\hline
\end{tabular}

Table 10. Original data and achieved grades for the public transportation network performance criteria for Stonnington, Bayswater, and Cockburn.

\begin{tabular}{ccccc}
\hline \multirow{2}{*}{ Criteria } & \multicolumn{2}{c}{ Original Data and Achieved Grade } \\
\cline { 2 - 4 } & $\begin{array}{c}\text { Public transport } \\
\text { network ratio }\end{array}$ & $17.64=$ Level D & $19.21=$ Level D & $60.78=$ Level A \\
\cline { 2 - 4 } $\begin{array}{c}\text { Busic public } \\
\text { transport } \\
\text { infrastructure } \\
\text { level }\end{array}$ & $\begin{array}{c}\text { Public transport } \\
\text { coverage ratio }\end{array}$ & $46.82=$ Level C & $50.42=$ Level B & $83.72=$ Level A \\
\cline { 2 - 4 } & $\begin{array}{c}\text { Harbor-type bus } \\
\text { stop setting ratio }\end{array}$ & $19.04=$ Level C & $9.2=$ Level D & $26.71=$ Level B \\
\cline { 2 - 4 } & $\begin{array}{c}\text { Public } \\
\text { transportation } \\
\text { priority lane } \\
\text { setting ratio }\end{array}$ & $0=$ Level E & $0.31=$ Level E & $25.38=$ Level A \\
\hline
\end{tabular}


Table 10. Cont.

\begin{tabular}{|c|c|c|c|c|}
\hline \multirow{2}{*}{\multicolumn{2}{|c|}{ Criteria }} & \multicolumn{3}{|c|}{ Original Data and Achieved Grade } \\
\hline & & Bayswater & Cockburn & Stonnington \\
\hline \multirow{4}{*}{$\begin{array}{l}\text { Public transport } \\
\text { service level }\end{array}$} & $\begin{array}{l}\text { Public transport } \\
\text { on-time rate }\end{array}$ & $91.03=$ Level B & 91.03 = Level B & $84.68=$ Level C \\
\hline & $\begin{array}{c}\text { Intersection } \\
\text { blocking rate } \\
\text { during peak } \\
\text { hours }\end{array}$ & $21=$ Level E & $8.1=$ Level D & $1.5=$ Level A \\
\hline & $\begin{array}{l}\text { Passenger } \\
\text { freight rate }\end{array}$ & $1.75=$ Level A & $1.75=$ Level A & $2.33=$ Level A \\
\hline & $\begin{array}{l}\text { Public transport } \\
\text { driving accident } \\
\text { rate }\end{array}$ & $2.38=$ Level C & 2.38 = Level C & $4.54=$ Level E \\
\hline \multirow{3}{*}{$\begin{array}{c}\text { Economic } \\
\text { benefit level }\end{array}$} & Coverage rate & $98.8=$ Level D & 98.8 = Level D & $101.5=$ Level B \\
\hline & $\begin{array}{l}\text { Bus ownership } \\
\text { rate }\end{array}$ & $7=$ Level D & 7 = Level D & $7.36=$ Level D \\
\hline & Intact car rate & $100=$ Level A & $100=$ Level A & $100=$ Level A \\
\hline \multirow{4}{*}{$\begin{array}{c}\text { Sustainable } \\
\text { development } \\
\text { level }\end{array}$} & $\begin{array}{c}\text { Public transport } \\
\text { land area per } \\
\text { capita }\end{array}$ & $20.47=$ Level A & $26.23=$ Level A & $9.28=$ Level B \\
\hline & $\begin{array}{c}\text { Public transport } \\
\text { utilization rate }\end{array}$ & $0.8=$ Level A & $0.8=$ Level A & $0.78=$ Level A \\
\hline & $\begin{array}{l}\text { Green public } \\
\text { transport vehicle } \\
\text { rate }\end{array}$ & $100=$ Level A & $100=$ Level A & $100=$ Level A \\
\hline & $\begin{array}{l}\text { Public transport } \\
\text { energy intensity }\end{array}$ & $25.45=$ Level A & $25.45=$ Level A & $83.59=$ Level C \\
\hline
\end{tabular}

Table 11. City public transportation evaluation result classification standard.

\begin{tabular}{cccccc}
\hline & Level A & Level B & Level C & Level D & Level E \\
\hline Index value evaluation range & $90-100$ & $80-90$ & $70-80$ & $60-70$ & $0-60$
\end{tabular}

Table 12. Comparative analysis of Bayswater, Cockburn, and Stonnington.

\begin{tabular}{|c|c|c|c|c|}
\hline \multirow{2}{*}{\multicolumn{2}{|c|}{ Criteria }} & \multicolumn{3}{|c|}{ Global Weight } \\
\hline & & Bayswater & Cockburn & Stonnington \\
\hline \multirow{4}{*}{$\begin{array}{c}\text { Basic public } \\
\text { transport } \\
\text { infrastructure } \\
\text { level }\end{array}$} & $\begin{array}{l}\text { Public transport } \\
\text { network ratio }\end{array}$ & 3.03 & 3.3 & 12.98 \\
\hline & $\begin{array}{l}\text { Public transport } \\
\text { coverage ratio }\end{array}$ & 10.52 & 11.56 & 14.3 \\
\hline & $\begin{array}{l}\text { Harbor-type bus } \\
\text { stop setting ratio }\end{array}$ & 2.97 & 1.66 & 3.5 \\
\hline & $\begin{array}{l}\text { Public } \\
\text { transportation } \\
\text { priority lane } \\
\text { setting ratio }\end{array}$ & 0 & 0.15 & 7.17 \\
\hline
\end{tabular}


Table 12. Cont.

\begin{tabular}{|c|c|c|c|c|}
\hline \multirow{2}{*}{\multicolumn{2}{|c|}{ Criteria }} & \multicolumn{3}{|c|}{ Global Weight } \\
\hline & & Bayswater & Cockburn & Stonnington \\
\hline \multirow{4}{*}{$\begin{array}{l}\text { Public transport } \\
\text { service level }\end{array}$} & $\begin{array}{l}\text { Public transport } \\
\text { on-time rate }\end{array}$ & 5.46 & 5.46 & 4.99 \\
\hline & $\begin{array}{l}\text { Intersection } \\
\text { blocking rate } \\
\text { during peak } \\
\text { hours }\end{array}$ & 0 & 2.91 & 4.26 \\
\hline & $\begin{array}{l}\text { Passenger } \\
\text { freight rate }\end{array}$ & 5.3 & 5.3 & 5.3 \\
\hline & $\begin{array}{l}\text { Public transport } \\
\text { driving accident } \\
\text { rate }\end{array}$ & 2.01 & 2.01 & 0.76 \\
\hline \multirow{3}{*}{$\begin{array}{c}\text { Economic } \\
\text { benefit level }\end{array}$} & Coverage rate & 3.34 & 3.34 & 3.86 \\
\hline & $\begin{array}{l}\text { Bus ownership } \\
\text { rate }\end{array}$ & 1 & 1 & 1.06 \\
\hline & Intact car rate & 1.9 & 1.9 & 1.9 \\
\hline \multirow{5}{*}{$\begin{array}{c}\text { Sustainable } \\
\text { development } \\
\text { level }\end{array}$} & $\begin{array}{c}\text { Public transport } \\
\text { land area per } \\
\text { capita }\end{array}$ & 7.8 & 7.8 & 6.62 \\
\hline & $\begin{array}{l}\text { Public transport } \\
\text { utilization rate }\end{array}$ & 2.99 & 2.99 & 3 \\
\hline & $\begin{array}{l}\text { Green public } \\
\text { transport vehicle } \\
\text { rate }\end{array}$ & 9 & 9 & 9 \\
\hline & $\begin{array}{l}\text { Public transport } \\
\text { energy intensity }\end{array}$ & 8.23 & 8.23 & 5.5 \\
\hline & Total & 63.55 & 66.61 & 82.45 \\
\hline
\end{tabular}

\section{Discussion and Conclusions}

In this study, we investigated the performance of public transport networks at the basic public transport infrastructure level, public transport service level, economic benefit level, and sustainable development level. The research established a new AHP-based model to provide weights for the criteria and sub-criteria. Based on the existing standards for each sub-standard, the new evaluation model gives a score for a city's public transportation network performance, and the results show the aspects that the government should consider improving in the future.

Moreover, we collected a series of indicators across three sample cities, representing a series of land use and transport policy backgrounds, and these indicators can help researchers to determine many standards that can inspire any city that wants to improve the future performance of its public transportation network. Results of the model show that all three cities have high levels of sustainable development. By providing indicators that can be used to evaluate specific public transport policy issues, this research has made a significant contribution to public transport network performance evaluation. The findings of this research are as follows:

- The public transport network ratio and public transport coverage ratio are the most important criteria for the basic public transport infrastructure level, whereas for the public transport service level, the public transport on-time rate has the highest weighting. For the economic benefit level, the coverage rate is the most important criterion. The green public transport vehicle rate and public transport energy intensity have the highest weighting in the area of sustainable development; 
- The results of the three case study areas indicate that both Bayswater and Cockburn should consider their public transport infrastructure level, public transport service level, and economic level more closely in their plans and strategies. Stonnington should improve its sustainable development level, public transport service level, and economic benefit level.

The results of this study can offer data for public transport planners to improve public transport in the future. More specifically, the established model and standards can be used as guidelines for optimizing the available resources. Furthermore, governments can use the results to propose strategies and policies to improve the performance of urban public transportation networks. In future work, more evaluation aspects and criteria can also be taken into consideration to adapt this model to various other cities.

Author Contributions: Conceptualization, G.L., S.W., L.B. and H.X.; methodology, G.L.; software, G.L.; validation, G.L.; formal analysis, G.L.; investigation, G.L.; writing—original draft preparation, G.L.; writing-review and editing, G.L., S.W., H.X. and C.L.; supervision, S.W. and C.L. All authors have read and agreed to the published version of the manuscript.

Funding: This research was funded by Australian Research Council, grant number LP160100528.

Institutional Review Board Statement: Not applicable.

Informed Consent Statement: Not applicable.

Data Availability Statement: The data presented in this study are available on request from the corresponding author.

Conflicts of Interest: The authors declare no conflict of interest.

\section{Appendix A}

Table A1. Formula for sub-criteria [26-30].

\begin{tabular}{|c|c|c|c|c|}
\hline \multicolumn{2}{|c|}{ Criteria } & Variables & $\begin{array}{c}\text { Mode of } \\
\text { Computation }\end{array}$ & Unit \\
\hline \multirow{4}{*}{$\begin{array}{l}\text { Basic public } \\
\text { transport } \\
\text { infrastructure } \\
\text { level }\end{array}$} & $\begin{array}{l}\text { Public transport } \\
\text { network ratio }\end{array}$ & $\begin{array}{c}\text { A1: Length of public } \\
\text { transport network } \\
\text { B1: Length of urban road } \\
\text { network }\end{array}$ & $(\mathrm{A} 1 / \mathrm{B} 1) \times 100$ & $\%$ \\
\hline & $\begin{array}{l}\text { Public transport } \\
\text { coverage ratio }\end{array}$ & $\begin{array}{l}\text { A2: A } 300 \text { m radius of } \\
\text { urban public } \\
\text { transportation service } \\
\text { area within an urban built } \\
\text { area (for a circle with a } \\
\text { radius of } 300 \text { m and a } \\
\text { center of public } \\
\text { transportation station, the } \\
\text { intersection part shall not } \\
\text { be counted twice) } \\
\text { B2: The area of urban } \\
\text { built zone }\end{array}$ & $(\mathrm{A} 2 / \mathrm{B} 2) \times 100$ & $\%$ \\
\hline & $\begin{array}{l}\text { Harbor type bus } \\
\text { stop setting ratio }\end{array}$ & $\begin{array}{l}\text { A3: The number of bus } \\
\text { stops of bay type } \\
\text { B3: Total number of stops }\end{array}$ & $(\mathrm{A} 3 / \mathrm{B} 3) \times 100$ & $\%$ \\
\hline & $\begin{array}{l}\text { Public } \\
\text { transportation } \\
\text { priority lane } \\
\text { setting ratio }\end{array}$ & $\begin{array}{l}\text { A4: The road length of the } \\
\text { public transport priority } \\
\text { lane is set on the main } \\
\text { road of the city. } \\
\text { B4: Total main road length }\end{array}$ & $(\mathrm{A} 4 / \mathrm{B} 4) \times 100$ & $\%$ \\
\hline
\end{tabular}


Table A1. Cont.

\begin{tabular}{|c|c|c|c|c|}
\hline \multicolumn{2}{|c|}{ Criteria } & Variables & $\begin{array}{c}\text { Mode of } \\
\text { Computation }\end{array}$ & Unit \\
\hline \multirow{4}{*}{$\begin{array}{l}\text { Public transport } \\
\text { service level }\end{array}$} & $\begin{array}{l}\text { Public transport } \\
\text { on-time rate }\end{array}$ & $\begin{array}{l}\text { A5: Bus on-time rate } \\
\text { B5: Rail transport } \\
\text { on-time rate } \\
\text { A5: }\left(\left(\sum \text { (the number of }\right.\right. \\
\text { departure on time }+ \text { the } \\
\text { number of arrive last } \\
\text { station on time }) / \sum \text { the } \\
\text { number of schedule } \\
\text { departure } \times 2) \times 100 \% \\
\text { B5: }\left(\left(\sum \text { (the number of }\right.\right. \\
\text { departure on time }+ \text { the } \\
\text { number of arrive last } \\
\text { station on time }) / \sum \text { the } \\
\text { number of schedule } \\
\text { departure } \times 2) \times 100 \%\end{array}$ & $(\mathrm{~A} 5+\mathrm{B} 5) / 2$ & $\%$ \\
\hline & $\begin{array}{c}\text { Intersection } \\
\text { blocking rate } \\
\text { during peak } \\
\text { hours }\end{array}$ & $\begin{array}{l}\text { A6: Number of } \\
\text { periodically severely } \\
\text { blocked intersections on } \\
\text { arterial roads in } \\
\text { built-up areas } \\
\text { B6: Total arterial road } \\
\text { intersections }\end{array}$ & $(\mathrm{A} 6 / \mathrm{B} 6) \times 100$ & $\%$ \\
\hline & $\begin{array}{l}\text { Passenger } \\
\text { freight rate }\end{array}$ & $\begin{array}{l}\text { A7: The cost of public } \\
\text { transportation paid by } \\
\text { passengers per month } \\
\text { B7: The city's monthly } \\
\text { average salary }\end{array}$ & $(\mathrm{A} 7 / \mathrm{B} 7) \times 100$ & $\%$ \\
\hline & $\begin{array}{l}\text { Public transport } \\
\text { driving accident } \\
\text { rate }\end{array}$ & $\begin{array}{l}\text { A8: The total number of } \\
\text { public transport accidents } \\
\text { in one year } \\
\text { B8: Total mileage of } \\
\text { public transport vehicles } \\
\text { operated in one year }\end{array}$ & A8/B8 & $\begin{array}{l}\text { Times/ } \\
\text { million } \\
\text { kilome- } \\
\text { ters }\end{array}$ \\
\hline \multirow{3}{*}{$\begin{array}{c}\text { Economic } \\
\text { benefit level }\end{array}$} & Coverage rate & $\begin{array}{l}\text { A9: Last year's total } \\
\text { commercial revenue } \\
\text { B9: Last year's total } \\
\text { operating expenses }\end{array}$ & $(\mathrm{A} 9 / \mathrm{B} 9) \times 100$ & $\%$ \\
\hline & $\begin{array}{l}\text { Bus ownership } \\
\text { rate }\end{array}$ & $\begin{array}{l}\text { A10: The number of } \\
\text { working buses in the } \\
\text { statistical period } \\
\text { B10: The number of urban } \\
\text { area population in case } \\
\text { study city }\end{array}$ & A10/B10 & $\begin{array}{c}\text { Car/ten } \\
\text { thou- } \\
\text { sand }\end{array}$ \\
\hline & Intact car rate & $\begin{array}{l}\text { A11: Intact car day } \\
\text { B11: Operating } \\
\text { vehicle-days }\end{array}$ & $(\mathrm{A} 11 / \mathrm{B} 11) \times 100$ & $\%$ \\
\hline
\end{tabular}


Table A1. Cont.

\begin{tabular}{|c|c|c|c|c|}
\hline \multirow{4}{*}{$\begin{array}{c}\text { Sustainable } \\
\text { development } \\
\text { level }\end{array}$} & $\begin{array}{c}\text { Public transport } \\
\text { land area per } \\
\text { capita }\end{array}$ & $\begin{array}{c}\text { A12: The area of roads } \\
\text { served by public transport } \\
\text { B12: Total urban } \\
\text { population }\end{array}$ & $\mathrm{A} 12 / \mathrm{B} 12$ & $\begin{array}{c}\mathrm{m}^{2} / \\
\text { person }\end{array}$ \\
\hline & $\begin{array}{c}\text { Public transport } \\
\text { utilization rate }\end{array}$ & $\begin{array}{l}\text { A13: The number of jobs } \\
\text { in public transportation } \\
\text { B13: Total number of } \\
\text { positions for the same } \\
\text { period (the number of } \\
\text { jobs in public } \\
\text { transportation, urban } \\
\text { planning and land use) }\end{array}$ & $\mathrm{A} 13 / \mathrm{B} 13$ & Null \\
\hline & $\begin{array}{l}\text { Green public } \\
\text { transport vehicle } \\
\text { rate }\end{array}$ & $\begin{array}{l}\text { A14: Number of green } \\
\text { public transport vehicles } \\
\text { B14: Total number of } \\
\text { public transport vehicle }\end{array}$ & $(\mathrm{A} 14 / \mathrm{B} 14) \times 100$ & $\%$ \\
\hline & $\begin{array}{l}\text { Public transport } \\
\text { energy intensity }\end{array}$ & $\begin{array}{l}\text { A15: Total public } \\
\text { transport energy } \\
\text { consumption } \\
\text { B15: Public transport } \\
\text { passenger turnover }\end{array}$ & A15/B15 & $\begin{array}{l}\text { g stan- } \\
\text { dard } \\
\text { coal/ } \\
\text { person- } \\
\text { km }\end{array}$ \\
\hline
\end{tabular}

\section{Appendix B}

Table A2. Level grade for all sub-criteria [26-30].

\begin{tabular}{|c|c|c|c|c|c|c|}
\hline & Level Grade & Level A & Level B & Level C & Level D & Level E \\
\hline \multirow{2}{*}{ Public transport network ratio (unit: \%) } & $\begin{array}{l}\text { Index value } \\
\text { interval }\end{array}$ & {$[60,70]$} & {$[55,60)$} & {$[50,55)$} & {$[0,50)$} & - \\
\hline & Score interval & {$[90,100]$} & {$[75,90)$} & {$[60,75)$} & {$[0,60)$} & - \\
\hline \multirow[t]{2}{*}{ Public transport coverage ratio (unit: \%) } & $\begin{array}{l}\text { Index value } \\
\text { interval }\end{array}$ & $\geq 55$ & {$[50,55)$} & {$[45,50)$} & {$[35,45)$} & $<35$ \\
\hline & Score interval & {$[90,100]$} & {$[80,90)$} & {$[70,80)$} & {$[60,70)$} & {$[0,60)$} \\
\hline \multirow{2}{*}{ Harbor type bus stop setting ratio (unit: \%) } & $\begin{array}{l}\text { Index value } \\
\text { interval }\end{array}$ & {$[35,100)$} & {$[25,35)$} & {$[15,25)$} & {$[0,15)$} & - \\
\hline & Score interval & {$[90,100]$} & {$[75,90)$} & {$[60,75)$} & {$[0,60)$} & - \\
\hline \multirow{2}{*}{$\begin{array}{l}\text { Public transportation priority lane setting } \\
\text { ratio (unit: \%) }\end{array}$} & $\begin{array}{l}\text { Index value } \\
\text { interval }\end{array}$ & $\geq 25$ & {$[20,25)$} & {$[15,20)$} & {$[10,15)$} & {$[0,10)$} \\
\hline & Score interval & {$[90,100]$} & {$[80,90)$} & {$[70,80)$} & {$[60,70)$} & {$[0,60)$} \\
\hline \multirow{2}{*}{ Public transport on-time rate (unit: \%) } & $\begin{array}{l}\text { Index value } \\
\text { interval }\end{array}$ & {$[95,100]$} & {$[85,95)$} & {$[70,85)$} & {$[0,70)$} & - \\
\hline & Score interval & {$[90,100]$} & {$[75,90)$} & {$[60,75)$} & {$[0,60)$} & - \\
\hline \multirow{2}{*}{$\begin{array}{l}\text { Intersection blocking rate during peak hours } \\
\text { (unit: \%) }\end{array}$} & $\begin{array}{l}\text { Index value } \\
\text { interval }\end{array}$ & {$[0,2]$} & $(2,5]$ & $(5,8]$ & $(8,11]$ & $>11$ \\
\hline & Score interval & {$[90,100]$} & {$[80,90)$} & {$[70,80)$} & {$[60,70)$} & {$[0,60)$} \\
\hline \multirow{2}{*}{ Passenger freight rate (unit: \%) } & $\begin{array}{l}\text { Index value } \\
\text { interval }\end{array}$ & $<3.5$ & {$[3.5,4.5)$} & {$[4.5,5.5)$} & {$[5.5,6.5)$} & $\geq 6.5$ \\
\hline & Score interval & {$[90,100]$} & {$[80,90)$} & {$[70,80)$} & {$[60,70)$} & {$[0,60)$} \\
\hline \multirow{2}{*}{$\begin{array}{l}\text { Public transport driving accident rate (unit: } \\
\text { times/million kilometers) }\end{array}$} & $\begin{array}{l}\text { Index value } \\
\text { interval }\end{array}$ & {$[0,1.5]$} & {$[1.5,2)$} & {$[2,2.5)$} & {$[2.5,3)$} & $>3$ \\
\hline & Score interval & {$[90,100]$} & {$[80,90)$} & {$[70,80)$} & {$[60,70)$} & {$[0,60)$} \\
\hline
\end{tabular}


Table A2. Cont.

\begin{tabular}{|c|c|c|c|c|c|c|}
\hline & Level Grade & Level A & Level B & Level C & Level D & Level E \\
\hline \multirow{2}{*}{ Coverage rate (unit: \%) } & $\begin{array}{l}\text { Index value } \\
\text { interval }\end{array}$ & $>150$ & $(100,150]$ & $=100$ & {$[50,100)$} & $<50$ \\
\hline & Score interval & {$[90,100]$} & {$[80,90)$} & {$[70,80)$} & {$[60,70)$} & {$[0,60)$} \\
\hline \multirow{2}{*}{ Bus ownership rate (unit: car/10,000) } & $\begin{array}{l}\text { Index value } \\
\text { interval }\end{array}$ & {$[20,25]$} & {$[19,20)$} & {$[18,19)$} & {$[0,18)$} & - \\
\hline & Score interval & {$[90,100]$} & {$[75,90)$} & {$[60,75)$} & {$[0,60)$} & - \\
\hline \multirow{2}{*}{ Intact car rate (unit: \%) } & $\begin{array}{l}\text { Index value } \\
\text { interval }\end{array}$ & $\geq 92$ & {$[88,92)$} & {$[84,88)$} & {$[80,84)$} & $<80$ \\
\hline & Score interval & {$[90,100]$} & {$[80,90)$} & {$[70,80)$} & {$[60,70)$} & {$[0,60)$} \\
\hline \multirow{2}{*}{$\begin{array}{l}\text { Public transport land area per capita (unit: } \\
\qquad \mathrm{m}^{2} / \text { person) }\end{array}$} & $\begin{array}{l}\text { Index value } \\
\text { interval }\end{array}$ & $\geq 11$ & {$[8,11)$} & {$[6,8)$} & {$[4,6)$} & $<4$ \\
\hline & Score interval & {$[90,100]$} & {$[80,90)$} & {$[70,80)$} & {$[60,70)$} & {$[0,60)$} \\
\hline \multirow{2}{*}{ Public transport utilization rate (unit: \%) } & $\begin{array}{l}\text { Index value } \\
\text { interval }\end{array}$ & {$[0.17,2)$} & {$[0.14,0.17)$} & {$[0.11,0.14)$} & {$[0.08,0.11)$} & $<0.08$ \\
\hline & Score interval & {$[90,100]$} & {$[80,90)$} & {$[70,80)$} & {$[60,70)$} & {$[0,60)$} \\
\hline \multirow{2}{*}{ Green public transport vehicle rate (unit: \%) } & $\begin{array}{l}\text { Index value } \\
\text { interval }\end{array}$ & $\geq 95$ & {$[95,92)$} & {$[88,92)$} & {$[85,88)$} & $<85$ \\
\hline & Score interval & {$[90,100]$} & {$[80,90)$} & {$[70,80)$} & {$[60,70)$} & {$[0,60)$} \\
\hline \multirow{2}{*}{$\begin{array}{l}\text { Public transport energy intensity (unit: } \mathrm{g} \\
\text { standard coal/person-km) }\end{array}$} & $\begin{array}{l}\text { Index value } \\
\text { interval }\end{array}$ & {$[0,30)$} & {$[30,80)$} & {$[80,130)$} & {$[130,200)$} & - \\
\hline & Score interval & {$[90,100]$} & {$[75,90)$} & {$[60,75)$} & {$[0,60)$} & - \\
\hline
\end{tabular}

\section{References}

1. Loukopoulos, P.; Jakobsson, C.; Gärling, T.; Schneider, C.M.; Fujii, S. Public attitudes towards policy measures for reducing private car use: Evidence from a study in Sweden. Environ. Sci. Policy 2005, 8, 57-66. [CrossRef]

2. Wang, S. The Function of Individual Factors on Travel Behaviour: Comparative Studies on Perth and Shanghai. In Proceedings of the State of Australian Cities Conference 2015, Gold Coast, Australia, 9-11 December 2015.

3. United Nations Human Settlements Programme. International Guidelines on Urban and Territorial Planning. Available online: https:/ / unhabitat.org/international-guidelines-on-urban-and-territorial-planning (accessed on 22 March 2021).

4. Barnum, D.; McNeil, S.; Hart, J. Comparing the efficiency of public transportation subunits using data envelopment analysis. J. Public Transp. 2007, 10, 1-16. [CrossRef]

5. Holmgren, J. The efficiency of public transport operations-An evaluation using stochastic frontier analysis. Res. Transp. Econ. 2013, 39, 50-57. [CrossRef]

6. Boujelbene, Y.; Derbel, A. The performance analysis of public transport operators in Tunisia using AHP method. Procedia Comput. Sci. 2015, 73, 498-508. [CrossRef]

7. Velasquez, M.; Hester, P.T. An analysis of multi-criteria decision making methods. Int. J. Oper. Res. 2013, 10, 56-66. Available online: https:/ / citeseerx.ist.psu.edu/viewdoc/download?doi=10.1.1.402.1308\&rep=rep1\&type=pdf (accessed on 22 March 2021).

8. Nosal, K.; Solecka, K. Application of AHP method for multi-criteria evaluation of variants of the integration of urban public transport. Transp. Res. Proc. 2014, 2014, 269-278. [CrossRef]

9. Daraio, C.; Diana, M.; Costa, F.D.; Leporelli, C.; Matteucci, G.; Alberto, N. Efficiency and effectiveness in the urban public transport sector: A critical review with directions for future research. Eur. J. Oper. Res. 2016, 248, 1-20. [CrossRef]

10. Orth, H.; Weidmann, U.; Dorbritz, R. Development of measurement system for public transport performance. Transp. Res. Rec. 2012, 2274, 135-143. [CrossRef]

11. Tiznado-Aitken, I.; Muñoz, J.C.; Hurtubia, R. Public transport accessibility accounting for level of service and competition for urban opportunities: An equity analysis for education in Santiago de Chile. J. Transp. Geogr. 2021, 90, 102919. [CrossRef]

12. Fadaei, M.; Cats, O. Evaluating the impacts and benefits of public transport design and operational measures. Transp. Policy 2016, 48, 105-116. [CrossRef]

13. Dragu, V.; Roman, E.A.; Roman, V.C. Quality assessment in urban public transport. Theor. Empir. Res. Urban Manag. 2013, 8, 32-43. Available online: https:/ / www.jstor.org/stable/24873355 (accessed on 22 March 2021).

14. Barabino, B.; Cabras, N.A.; Conversano, C.; Olivo, A. An integrated approach to select key quality indicators in transit services. Soc. Indic. Res. 2020, 149, 1045-1080. [CrossRef] 
15. Sezhian, M.V.; Muralidharan, C.; Nambirajan, T.; Deshmukh, S.G. Developing a performance importance matrix for a public sector bus transport company: A case study. Theor. Empir. Res. Urban Manag. 2011, 6, 5-14. Available online: https://www.jstor. org/stable/24873289 (accessed on 22 March 2021).

16. Curtis, C.; Scheurer, J. Performance measures for public transport accessibility: Learning from international practice. J. Transp. Land Use 2017, 10, 93-118. Available online: https:/ / www.jstor.org/stable/26211723 (accessed on 22 March 2021). [CrossRef]

17. Curtis, C.; Scheurer, J. The SNAMUTS Accessibility Tool in Action. In Designing Accessibility Instruments: Lessons on Their Usability for Integrated Land Use and Transport Planning Practices; Silva, C., Bertolini, L., Pinto, N., Eds.; Routledge: New York, NY, USA, 2019; ISBN 978-131-546-361-2.

18. Ona, J.D.; Oña, R.D.; Diez-Mesa, F.; Eboli, L.; Mazzulla, G. A composite index for evaluating transit service quality across different user profiles. J. Public Transp. 2016, 19, 128-153. [CrossRef]

19. Jain, S.; Aggarwal, P.; Kumar, P.; Singhal, S.; Prateek, S. Identifying public preferences using multi-criteria decision making for assessing the shift of urban commuters from private to public transport: A case study of Delhi. Transp. Res. Part F Traffic Psychol. Behav. 2014, 24, 60-70. [CrossRef]

20. Pohekar, S.D.; Ramachandran, M. Application of multi-criteria decision making to sustainable energy planning-A review. Renew. Sustain. Energy Rev. 2004, 8, 365-381. [CrossRef]

21. Yedla, S.; Shrestha, R.M. Multi-criteria approach for the selection of alternative options for environmentally sustainable transport system in Delhi. Transp. Res. Part A Pol. Pract. 2003, 37, 717-729. [CrossRef]

22. Sadeghi, M.; Ameli, A. An AHP decision making model for optimal allocation of energy subsidy among socio-economic subsectors in Iran. Energy Policy 2012, 45, 24-32. [CrossRef]

23. Saaty, T.L. Highlights and critical points in the theory and application of the analytic hierarchy process. Eur. J. Oper. Res. 1994, 74, 426-447. [CrossRef]

24. Saaty, T.L. A scaling method for priorities in hierarchical structures. J. Math. Psychol. 1977, 15, 234-281. [CrossRef]

25. Saaty, T.L. The analytic hierarchy process-What it is and how it is used. Math. Model. 1987, 9, 161-176. [CrossRef]

26. Passenger Transport Services for Bus/Trolleybus GB/T22484-2008. Available online: https://wenku.baidu.com/view/9c31952 8e2bd960590c677e6.html (accessed on 22 March 2021).

27. GBT 22484-2016 Passenger Transport Services Specifications for Urban Bus/Trolleybus. Available online: https:/ / pan.baidu. com/s/1eSeT2N4 (accessed on 22 March 2021).

28. Urban Road Traffic Management Evaluation Index System 2012 Edition. Available online: https://wenku.baidu.com/view/20e4 368f84868762caaed5a1.html (accessed on 22 March 2021).

29. Evaluation Index System of Public Transportation City Assessment. Available online: https://wenku.baidu.com/view/1015f2 8a360cba1aa811dac1.html (accessed on 22 March 2021).

30. Code for Transport Planning on Urban Road GB50220-1995. Available online: https://wenku.baidu.com/view / fa103f6b0b4c2e3 f57276369.html (accessed on 22 March 2021). 